\title{
Anti-diabetic effects of Campomanesia xanthocarpa (Berg) leaf decoction
}

\author{
Anapaula Sommer Vinagre ${ }^{1,2, *}$, Ângela Della'Santa Rubio Origuella Rönnau², Sabrina Francisco \\ Pereira $^{2}$, Lídia Uliano da Silveira ${ }^{1}$, Elenir de Fátima Wiilland ${ }^{1,2}$, Edna Sayuri Suyenaga ${ }^{3}$ \\ ${ }^{1}$ Animal Histophysiology Laboratory, Faculty of Biology, Lutheran University of Brazil, ${ }^{2}$ Faculty of Pharmacy, Lutheran \\ University of Brazil, ${ }^{3}$ Faculty of Pharmacy, Feevale University Center
}

\begin{abstract}
The objective of this research was to identify the effects of 3-week treatment of normal and streptozotocininduced diabetic rats using a leaf decoction of Campomanesia xanthocarpa Berg. $(20 \mathrm{~g} / \mathrm{L})$ on physiological, biochemical and histological parameters. Streptozotocin (STZ, $70 \mathrm{mg} / \mathrm{kg}$ in citrate buffer, $\mathrm{pH}$ 4.5) was administered IP to induce experimental diabetes one week prior to the treatment. STZ caused typical diabetic symptoms: polydypsia, polyuria, polyphagia, hyperglycemia, hypertriglyceridemia and histopathological modifications in the pancreas, liver and kidney. The treatment of diabetic rats using the decoction decreased blood glucose levels, inhibited hepatic glycogen loss, and prevented potential histopathological alterations in the pancreas and kidneys. No differences were found between the control rats treated with the decoction and the control rats maintained on water only. In conclusion, these results suggest that C. xanthocarpa leaf decoction $(20 \mathrm{~g} / \mathrm{L})$ might be useful for diabetes mellitus management, but further pharmacological and toxicological studies are needed.
\end{abstract}

Uniterms: Campomanesia xanthocarpa/pharmacognosy. Diabetes Mellitus/experimental study. Hypoglycemic plant. Histology. Carbohydrate/metabolism. Lipid/metabolism.

\begin{abstract}
O objetivo deste trabalho foi identificar os efeitos do tratamento com o decocto das folhas de Campomanesia xanthocarpa Berg. $(20 \mathrm{~g} / \mathrm{L})$, durante 3 semanas, sobre parâmetros fisiológicos, bioquímicos e histológicos de ratos normais e diabéticos induzidos por estreptozotocina. O diabete melito foi induzido uma semana antes de iniciar o tratamento experimental, pela administração IP de estreptozotocina (STZ, $70 \mathrm{mg} /$ kg em tampão citrato, $\mathrm{pH} 4.5$ ). Os ratos tratados com STZ apresentaram sintomas típicos de diabete: polifagia, polidipsia, hiperglicemia, hipertrigliceridemia e alterações histopatológicas no pâncreas, fígado e rim. O tratamento dos ratos diabéticos com o decocto diminuiu os níveis de glicose sanguínea, inibiu a degradação do glicogênio hepático e preveniu possíveis alterações histopatológicas no pâncreas e no rim. Nos ratos controles tratados com o decocto não foram verificadas diferenças significativas em relação aos controles tratados com água. Em conclusão, os resultados sugerem que o tratamento com o decocto das folhas de C. xanthocarpa leaf decoction $(20 \mathrm{~g} / \mathrm{L})$ possa ser útil para o manejo do diabete melito, porém estudos farmacológicos e toxicológicos ainda são necessários.
\end{abstract}

Unitermos: Campomanesia xanthocarpa/farmacognosia. Diabete Melito/estudo experimental. Planta hipoglicemiante. Carboidratos/metabolismo. Lipídeos/metabolismo.

\section{INTRODUCTION}

More than 170 million people are affected by diabetes worldwide, an incidence estimated to rise $50 \%$ by

\footnotetext{
*Correspondence: A. S. Vinagre. Departamento de Fisiologia, Instituto de Ciências Básicas da Saúde, Universidade Federal do Rio Grande do Sul. Rua Sarmento Leite, 500 - 90050-170 - Porto Alegre - RS, Brazil. E-mail: apvinagre@uol.com.br
}

2030 , with the greatest increases set to occur in the developing countries of Africa, Asia and South America (WHO, 2008). In Brazil, 7.6 \% of the population aged between 30 and 69 years has diabetes, with the cities of São Paulo and Porto Alegre registering the highest percentages: 9.7 and $8.9 \%$, respectively (Salgado, 1998). Diabetes mellitus is a chronic metabolic disease characterized by hyperglycemia and disturbances in carbohydrate, fat and protein metabo- 
lism. It is associated with an absolute or relative deficiency in the secretion of insulin (Diabetes Mellitus 1, DM1) or with insulin resistance (Diabetes Mellitus 2, DM2) (Savage et al., 2007; Stumvoll et al., 2005). DM2 is the most common form of the disease, accounting for 85 to $90 \%$ of all recorded cases (Tiwari, Rao, 2002). Besides hyperglycemia, hyperlipidemia is involved in the development of the micro and macro vascular complications of diabetes, which are the major causes of morbidity and death (Tang et al., 2006). Despite the great efforts made to better understand and manage this disease, serious problems such as retinopathy, nephropathy and lower extremity amputation continue to affect patients, while diabetes-related mortality is rising unabated (Tiwari, Rao, 2002). Insulin resistance can also lead to Metabolic Syndrome (MS), a complex metabolic disease characterized by obesity, hypertension, dyslipidemia and DM2 (Sanchéz-Salgado et al., 2007). The current rise in DM2 and MS is believed to be a result of an increase in the sedentary life styles combined with ready access to energy-rich food sources in genetically susceptible individuals (Savage et al., 2007).

Treatment of diabetes involves diet control, exercise and the use of hypoglycemic or lipid-lowering drugs such as insulin, sulphonylureas, biguanides and thiazolinediones (Stumvoll et al., 2005). However, many oral medicines have a number of serious adverse effects, and the management of hyperglycemia and hyperlipidemia with low side effects is still a challenge for the medical system (Revilla-Monsalve et al., 2007). Another problem faced is the cost of the treatment, which is often prohibitively high in developing countries (Schoenfelder et al., 2006). In Brazil, some 200 plants are popularly used for the management of diabetes (Barbosa-Filho et al., 2005). Such plants are used in formulations of home-made medicines such as teas, decoctions and tinctures (Schoenfelder et al., 2006). The main phytochemicals described as useful for treating diabetes are terpenoids, coumarines, flavonoids, alkaloids, phenolic substances and lecitines (BarbosaFilho et al., 2005).

Campomanesia xanthocarpa Berg., popularly known as gabiroba, is a common species in the forests of the Southern, Southeastern and Midwestern regions of Brazil, and is also found in Uruguay, Paraguay and Argentina. The infusion prepared from its leaves is commonly used as a depurative, anti-diarrheic, cleanser, anti-rheumatic, and to lower blood cholesterol (Ballvé et al., 1995). Recently, Dickel et al. (2007) confirmed that it is popularly used to reduce obesity by the population of Porto Alegre, in the southern region of Brazil. Despite its popular use, there is scant pharmacological information available on this plant. Markman et al. (2004) described the anti-ulcerogenic activity of the alcoholic extract and Fernandes and Vargas (2003) demonstrated mutagenic and anti-mutagenic potential. The chronic treatment of obese rats with the infusion of the leaves of C. xanthocarpa led to a significant decrease in body mass, as well as a reduction in glycemia (Biavatti et al., 2004). Since C. xanthocarpa caused a hypoglycemic effect in obese rats, the objectives of this research were to verify the effects of the chronic treatment of normal and streptozotocin-induced diabetic rats using a leaf decoction of C. xanthocarpa $(20 \mathrm{~g} / \mathrm{L})$ on physiological, biochemical and histopathological parameters.

\section{MATERIAL AND METHODS}

\section{Plant material}

Campomanesia xanthocarpa leaves were collected in Gravataí, Rio Grande do Sul State, Brazil, and were identified by Dr. Sérgio Bordignon. An exsiccate (voucher specimen) was deposited in the Herbarium of the Lutheran University of Brazil (ULBRA) under the code 1715. The leaves were kept in a dry and ventilated place, protected from light, and were dried and powdered. The decoct $(20 \mathrm{~g} / \mathrm{L})$ was prepared daily, boiled for 10 minutes and when reaching room temperature, the solution was filtered and administered to the rats as a drinkable solution.

\section{Rats and experimental design}

Male Wistar rats weighing $164.97 \pm 11.69 \mathrm{~g}$ (mean \pm SEM, $n=70$ ), bred at our animal facility, were used in this study. The rats were housed in an environmentallycontrolled room with a $12 \mathrm{~h}$ light: $12 \mathrm{~h}$ dark cycle (lights on at 7:00 am) at a constant temperature of $23{ }^{\circ} \mathrm{C}$. All the experimental procedures were carried out in accordance with the guidelines of the Brazilian College of Animal Experimentation (COBEA), and the experimental protocol was approved by the Research Ethics Committee of the Lutheran University of Brazil and registered under the number 2004-024A.

A freshly-prepared solution of streptozotocin (STZ, $70 \mathrm{mg} / \mathrm{kg} / \mathrm{bw}$ ) in $0.1 \mathrm{M}$ citrate buffer, $\mathrm{pH} 4.5$ was injected intraperitoneally to rats that had fasted overnight (Kesari et al., 2007). One week later, blood samples were collected from the orbital sinus, and rats with fasting blood glucose (FBG) levels above $200 \mathrm{mg} / \mathrm{dL}$ (11.1 mmol/L) were selected for the experimental protocol.

During a 21-day period of treatment, normal and STZ-treated rats were fed with $40 \mathrm{~g} /$ day of pelleted food (Nuvital, Nuvilab CR1, Curitiba, PR, Brazil) and divided into four drinking groups: 
- $\quad$ Group I(WC): water (negative) control; control rats which received $100 \mathrm{~mL}$ of water a day $(\mathrm{n}=15)$.

Group II (WD): water (untreated) diabetic; STZtreated rats which received $100 \mathrm{~mL}$ of water a day $(\mathrm{n}=16)$.

- $\quad$ Group III (DC): decoct (positive) control; control rats which received $100 \mathrm{~mL}$ of $C$. xanthocarpa $(20 \mathrm{~g} / \mathrm{L})$ decoction a day $(\mathrm{n}=19)$.

- $\quad$ Group IV (DD): decoct diabetic; STZ-treated rats which received $100 \mathrm{~mL}$ of $C$. xanthocarpa $(20 \mathrm{~g} / \mathrm{L})$ decoction a day $(n=19)$.

At the end of the second week of treatment, the rats were transferred to individual metabolic cages where they were kept for a further week. During this period, the total amount of food and drink ingested were measured daily, as was urine volume. Throughout the experimental period, blood samples were collected weekly from the eyes (venous pool) under mild ether anesthesia ( 30 seconds of exposure) and collected in Eppendorfs with $0.1 \mathrm{~mL}$ of sodium citrate as anti-clotting agent. After centrifugation, the plasma samples were stored frozen for later biochemical analysis.

On the last day of the treatment, after a 12-hour period of fasting, the rats were sacrificed by decapitation after mild ether anesthesia. Blood and organ samples (liver, diaphragm, kidney and pancreas) were collected. The blood samples were obtained by means of heart puncture with 0.1 $\mathrm{mL}$ of sodium citrate. After centrifugation, the plasma was separated and stored frozen for the subsequent biochemical assays. The body weight of the rats was also monitored.

\section{Biochemical analysis}

Blood glucose was determined by the glucose oxidase method using glucose diagnostic kits HK-Liquiform (Labtest Diagnóstica). Plasma triglycerides and total cholesterol were also determined using diagnostic kits: Triglycerides GPO-ANA (Labtest Diagnóstica) and cholesterol-liquiform (Labtest Diagnóstica).

Liver samples used for glycogen determination were collected using the freeze-clamp procedure with aluminum tongs and stored frozen. The glycogen extraction followed the method of van Handel (1965) and the values were determined as glucose equivalents after acid hydrolysis $(\mathrm{HCl})$ and neutralization $\left(\mathrm{Na}_{2} \mathrm{CO}_{3}\right)$, according to the method of Geary et al. (1981). The results obtained were expressed as $\mathrm{mg} / \mathrm{g}$ of tissue.

\section{Histological analysis}

For the histopathological analysis, samples of the liver, pancreas and kidney were preserved in $10 \%$ formaldehyde for 24 hours and processed following the routine procedure described by Tolosa et al. (2003): the tissues were blocked in Histosec and serial slices $(7 \mu \mathrm{m}-$ thick) were obtained using a Microtome (Microtome RM 2025), stained with hematoxylin-eosin, and analyzed under an optical microscope (Leica CME). Pancreas samples were also stained with Gomori's aldehydefuchsin, a procedure for identifying the effects of the treatments on $\beta$ cells (Tolosa et al., 2003; Diani et al., 2004). Photographs were taken using a digital camera (SONY DSC-W1) attached to the microscope.

\section{Statistical analysis}

The results were expressed as mean \pm S.E.M. (standard error). Comparisons were made using one-way ANOVA followed by Duncan's and Bonferroni's post-hoc tests. In all comparisons, values of $p<0.05$ were considered statistically significant. Statistical tests were performed using the SPSS program (Statistical Package for Social Sciences, version 10.0, for Windows).

\section{RESULTS AND DISCUSSION}

\section{Physiological results}

The difference between the final and initial weights of the rats is shown in Table I. In the control groups, the total body weight of the rats increased, while this weight gain was lower in the diabetic groups $(\mathrm{p}>0.05)$. The hepatosomatic index (HI) represents the weight of the liver in relation to total body weight (Table I) and no significant difference $(\mathrm{p}>0.05)$ was detected in $\mathrm{HI}$ among the experimental groups. The amount of food ingested during the last week of treatment (Table I) increased significantly $(\mathrm{p}<0.05)$ in the control group treated with $C$. xanthocarpa decoct, as well as in both diabetic groups (WD and DD) compared to the untreated control group. The volume of liquid ingested and the urinary flux of both diabetic groups increased $(p<0.05)$ in relation to the two control groups. In the present study, STZ induced typical signs of diabetes including reduced weight gain, polyphagia, polydypsia and polyuria, (Cavalli et al., 2007; Dobrzynski et al., 2002). It is interesting to note that the C.xanthocarpa decoction had no diuretic effect in the control or diabetic groups, a common side effect of many teas and herbal infusions. The final ingested dose of C. xanthocarpa decoct was $0.737 \mathrm{~g} / \mathrm{mL}$ for the control rats and $1.65 \mathrm{~g} / \mathrm{mL}$ for the diabetic rats. 
TABLE I - Physiological parameters of control and diabetic rats treated with the decoct of $C$. xanthocarpa or water. $\Delta$ W: Weight gain, difference between the final and initial weights of the rats. The values are expressed as mean \pm S.E.M.

\begin{tabular}{lcccc}
\hline Treatment & Water Control & C. xanthocarpa Control & Water Diabetic & C. xanthocarpa Diabetic \\
\hline$\Delta \mathrm{W}(\mathrm{g})$ & $156.20 \pm 15.06$ & $176.141 \pm 16.83$ & $53.573 \pm 17.68^{*}$ & $26.74 \pm 11.55^{*}$ \\
Hepatosomatic Index & $3.22 \pm 0.16$ & $3.23 \pm 0,15$ & $2.99 \pm 0.17$ & $3.03 \pm 0.14$ \\
Ingested Food (g/day) & $21.61 \pm 0.46$ & $25.46 \pm 0.25^{*}$ & $30.03 \pm 0.29^{* \mathrm{a}}$ & $34.76 \pm 0.24^{* \mathrm{a}}$ \\
Ingested Drink (mL/day) & $38.03 \pm 2.29$ & $36.85 \pm 1.99$ & $84.92 \pm 4.44^{*}$ & $82.59 \pm 1.06^{*}$ \\
Urine (mL/day) & $7.20 \pm 2.39$ & $7.16 \pm 2.38$ & $39.11 \pm 1.2^{*}$ & $42.02 \pm 1.55^{*}$ \\
\hline
\end{tabular}

*: Statistically significant difference compared to water control group $(\mathrm{p}<0.05)$.

a: Statistically significant difference compared to decoct control group $(\mathrm{p}<0.05)$.

\section{Biochemical results}

One week after the administration of streptozotocin, the levels of plasma glucose (Figure 1) had significantly increased $(p<0.05)$ in both groups of STZ-treated rats in relation to the control groups. Only those rats with blood glucose above $13.875 \mathrm{mmol} / \mathrm{L}(250 \mathrm{mg} / \mathrm{dL})$ were considered diabetic. Neither of the control groups showed any significant variation in blood glucose during the experiment $(p>0.05)$. At the end of the treatment, the diabetic rats that received $C$. xanthocarpa decoct showed a $26 \%$ reduction in blood glucose $(\mathrm{p}<0.05)$ in relation to the untreated diabetic group. This finding is in agreement with the description of Biavatti et al. (2004), which reported a $15 \%$ reduction in the plasma glucose level of obese rats (induced with a hypercaloric diet) treated with C. xanthocarpa. In other pharmacological investigations involving hypoglycemic plants, a 12 to $20 \%$ reduction in blood glucose level was considered significant (SánchezSalgado et al., 2007 and Cavalli et al., 2007). In the control rats treated with C. xanthocarpa, blood glucose levels displayed no significant variation. According to Kesari et al. (2007), this is also a relevant result, demonstrating that continuous use of the decoct will not result in hypoglycemic shock, usually the case when insulin or sulfonylurea drugs are taken in excessive doses.

The values of total cholesterol (Table II) in the plasma of all tested groups displayed no significant alteration $(p>0.05)$ during the experimental period. However, in both diabetic groups, blood triglycerides levels (Table II) had increased significantly $(\mathrm{p}<0.05)$ in relation to the untreated control group by the end of the experimental period. The levels of serum lipids are usually high in diabetes mellitus, where such elevation represents a risk factor for coronary heart disease (Kesari et al., 2007; Pushparaj et al., 2007; Savage et al., 2007). This abnormally high level of serum lipids is mainly due to the uninhibited action of lipolytic hormones on fat deposits (Pushparaj

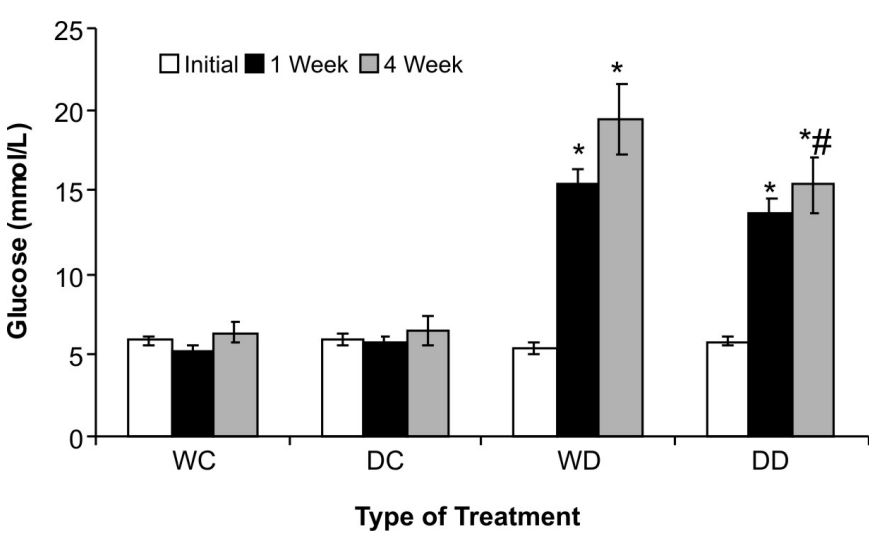

FIGURE 1 - Plasma glucose levels (mmol/L) of control and diabetic rats treated with decoct of C. xanthocarpa or water. WC: control rats treated with water; DC: control rats treated with decoct; WD: diabetic rats treated with water; DD: diabetic rats treated with decoct. Columns represent means, and bars represent S.E.M. *: Statistically significant difference compared to water control group $(\mathrm{p}<0.05)$. \#: Statistically significant difference compared to water diabetic group $(\mathrm{p}<0.05)$.

et al., 2007; Savage et al., 2007). Hypercholesterolemia and hypertriglyceridemia may also occur in STZ-treated rats (Pushparaj et al., 2007). In the present study, only triglycerides displayed a significant increase in STZ treated rats, whereas C. xanthocarpa decoct caused no significant variation in triglyceride levels. This finding is in line with the description of Biavatti et al. (2004), which reported no significant effects of C. xanthocarpa on the lipid levels of rats fed with a hypercaloric diet. This result suggests that the popular use of C. xanthocarpa as an anti-obesity treatment (Dickel et al., 2007) should not be encouraged until further pharmacological studies have been undertaken.

The levels of glycogen in the liver at the end of the treatment are shown in Table II. The untreated diabetic rats displayed a $36 \%$ reduction $(\mathrm{p}<0.05)$ in hepatic glycogen in relation to the untreated control group. On the other hand, the hepatic glycogen levels of the diabetic 
TABLE II - Biochemical parameters in plasma and liver of control and diabetic rats treated with decoct of $C$. xanthocarpa or water. Values are expressed as mean \pm S.E.M.

\begin{tabular}{lcccc}
\hline Treatment & Water Control & C. xanthocarpa Control & Water Diabetic & C. xanthocarpa Diabetic \\
\hline Total Cholesterol (mmol/ L) & $1.016 \pm 0.078$ & $1.225 \pm 0.121$ & $1.074 \pm 0.067$ & $1.075 \pm 0.108$ \\
Triglycerides (mmol/ L) & $0.442 \pm 0.040$ & $0.575 \pm 0.060$ & $0.684 \pm 0.079^{*}$ & $0.690 \pm 0.068^{*}$ \\
Liver Glycogen $(\mathrm{mg} / \mathrm{g}$ of tissue) & $147.93 \pm 20.19$ & $123.10 \pm 20.20$ & $95.43 \pm 15.89^{*}$ & $130.78 \pm 27.30$ \\
\hline
\end{tabular}

*: Statistically significant difference compared to water control group $(\mathrm{p}<0.05)$.

a: Statistically significant difference compared to decoct control group $(\mathrm{p}<0.05)$.

rats treated with $C$. xanthocarpa decoct were similar to those of the untreated control group $(\mathrm{p}>0.05)$. The liver plays a pivotal role in maintaining energy homeostasis during feeding/fasting transitions. While the peripheral tissues, predominantly skeletal muscle, account for the majority of the postprandial insulin-stimulated glucose disposal, the liver also plays a key role in buffering ingested carbohydrate by suppressing hepatic glucose output and stimulating glucose deposition as liver glycogen. In the fasting state, hepatic glycogen stores are rapidly mobilized to maintain circulating glucose concentrations, representing around $50 \%$ of endogenous glucose production in the first hours of fasting, while gluconeogenesis accounts for the remaining 50\% (Savage et al., 2007). In this study, the untreated diabetic rats displayed a $36 \%$ reduction in hepatic glycogen in relation to the untreated control group, a common feature of diabetes. In the diabetic state, the absence of insulin leads to decreased liver glycogen synthesis which enhances plasma glucose levels. In addition, glucagon levels are high in this condition, stimulating glycogenolysis and gluconeogenesis, and resulting in reduced liver glycogen (Jhiang, Zhang, 2003). Thus, the reduced glycogen levels in diabetic patients can be explained by reduced glycogen synthesis, and also by an increase in glycogenolysis and gluconeogenesis (Ferreira et al., 2001; Grover et al., 2002; Savage et al., 2007). On the other hand, hepatic glycogen of the diabetic rats treated with C. xanthocarpa decoct was similar to the untreated control group, suggesting that this treatment was able to restore or preserve liver glycogen. A similar effect was reported by Grover et al. (2002) in diabetic mice (STZ induced) treated with Eugenia jambolana $(200 \mathrm{mg} / \mathrm{kg} / \mathrm{day})$. These authors stated that this effect can be explained by a possible stimulatory effect of the extract on insulin release from $\beta$ cells, either by the insulinomimetic action of a component present in the extract, or by a combination of the two processes. More recently, Oliveira et al. (2008) reported an increase in liver glycogen in STZ-diabetic rats treated with Vatairea macrocarpa extract.

\section{Histopathological results}

Representative photomicrographs from the HEstained tissue sections are shown in Figures 2 and 3. The pancreatic islets from both control groups displayed normal histological features: the islets are oval (Figure 2A) and spread throughout the exocrine structures, the acinis. This finding is in agreement with the description of Tang et al. (2006). The Gomori stain (Figures 2B and 2C) demonstrates that $\beta$ cells are found mainly in the central region of the islets, while some are in the peripheral region. The cytoplasm of these cells displays green stain, confirming the presence of insulin granules, as described by Diani et al. (2004). In the untreated diabetic rats (Figure 2D), the islets have shrunk: they have a reduced diameter and irregular shape, with a small number of cells and vacuolization of the cytoplasm. The same pattern was described by Tang et al. (2006). The Gomori stain (Figure 2E) did not display green stain, indicating the absence of insulin granules, in accordance with the description of Diani et al. (2004). In the diabetic group treated with the decoction (Figure 2F) the shape of the islet is not as irregular, and green stains are present, indicating the presence of insulin. This finding suggests that the treatment of STZ-diabetic rats with $C$. xanthocarpa decoction can reduce some of the damage induced by STZ. According to Tiwari and Rao (2002), it is practically impossible to regenerate $\beta$ cells once they are destroyed. However, the crude extract of Pterocarpus marsupium, an Ayurvedic medicinal plant, has been reported to confer protective and restorative effects on alloxan-induced diabetic rats. These results were reported through histological observations, together with a notable improvement in blood sugar levels. Another medicinal plant reported to have beneficial effects on islet morphology is the bitter melon Momordica charantia (Ahmed et al., 1998). A recent histological analysis of alloxan-induced diabetic rats treated with berberine, the main active constituent of Rhizoma coptidis, showed that it was able to alleviate the progression of diabetes (Tang et al., 2006). According to these authors, the mechanism of action of 
berberine remains unclear, but effects may be related to its ability to scavenge free radicals. The damage induced in $\beta$ cells by STZ in rats can also be slowed or prevented by treatment with thiazolinediones (rosiglitazone, troglitazone or pioglitazone) in the early stages of the disease (Diani et al., 2004; Higa et al., 1999). The prevention of $\beta$ cell destruction by thiazolinediones is linked to their anti-inflammatory action on glucose-mediated IL- $1 \beta$, as well as to their ability to decrease islet triglyceride content, which if left untreated, generates nitric oxide leading to both diminished islet cell viability and mitochondrial biogenesis (Diani et al., 2004).
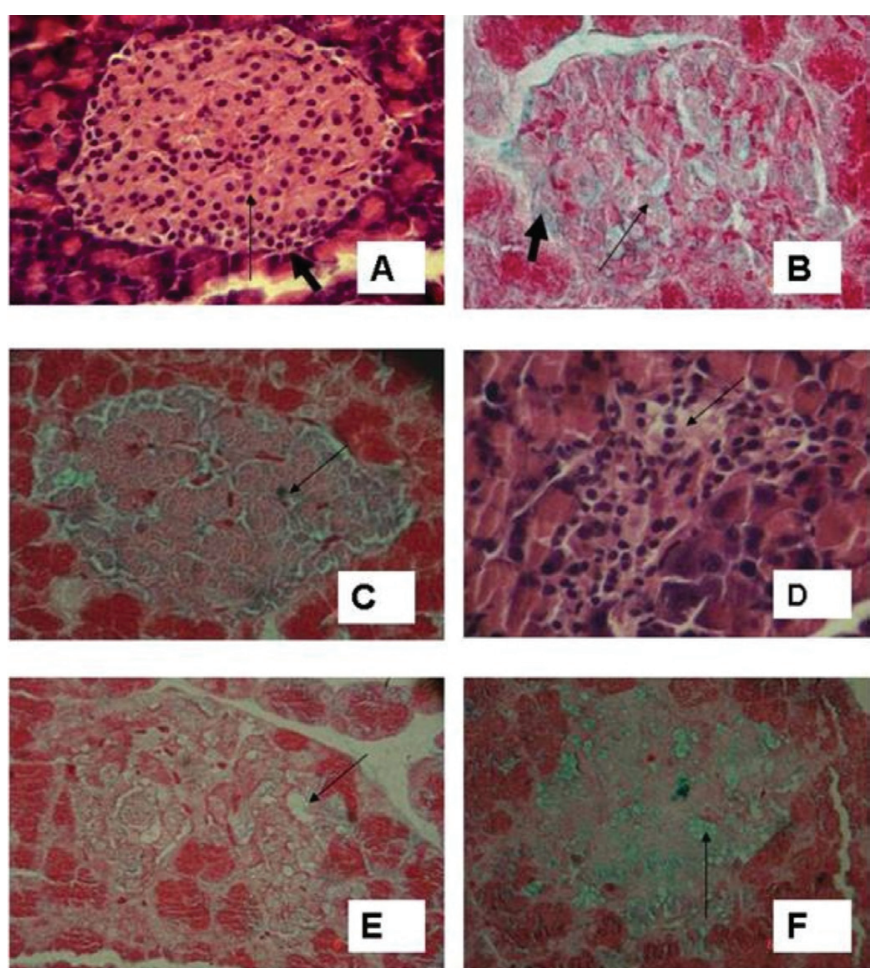

FIGURE 2 - Photomicrographs (400X) showing effects of different treatments on histopathological parameters of pancreatic islets. A: Photomicrograph of normal pancreatic islet from water control group, islets cells (thin arrow), conjunctive tissue (large arrow), HE stained. B: Photomicrograph of normal pancreatic islet from water control group, Gomori-stained, showing insulin granules (green spots) within $\beta$ cells (thin arrow), conjunctive tissue (large arrow). C: Photomicrograph of normal pancreatic islet from decoct treated control group, Gomori-stained displaying insulin granules within $\beta$ cells (arrow). D: Pancreatic islet from untreated diabetic group displaying altered shape and cytoplasmatic vacuolization (arrow), HE stained. E: Pancreatic islet from untreated diabetic group stained with Gomori, displaying altered shape, cytoplasmatic vacuolization (arrow) and absence of $\beta$ cells, 400X. F: Pancreatic islet from diabetic group treated with decoct, Gomori-stained, displaying less altered shape and presence of $\beta$ cells with insulin granules (arrow).
The liver of the control rats (Figure 3A) presented typical histological organization, matching the description of Teckman et al. (2002). In control rats treated with $C$. xanthocarpa decoction, the liver also displayed typical histological organization, except for an inflammatory process in the stroma and hypertrophic nuclei in some of the hepatocytes. In both groups of diabetic rats, the hepatocytes were enlarged, with vacuolar cytoplasm and hypertrophic nuclei. The stroma displayed discreet disorganization with enlargement of the space between the hepatocyte plaques, sinusoidal dilatation, and an infiltrative inflammatory process in the periportal region (Figure 3B). These results indicate that the treatment with C. xanthocarpa decoct was unable to prevent these morphological alterations in the liver. Further histopathological and toxicological studies are necessary in order to better evaluate the effects of $C$. xanthocarpa on the liver.
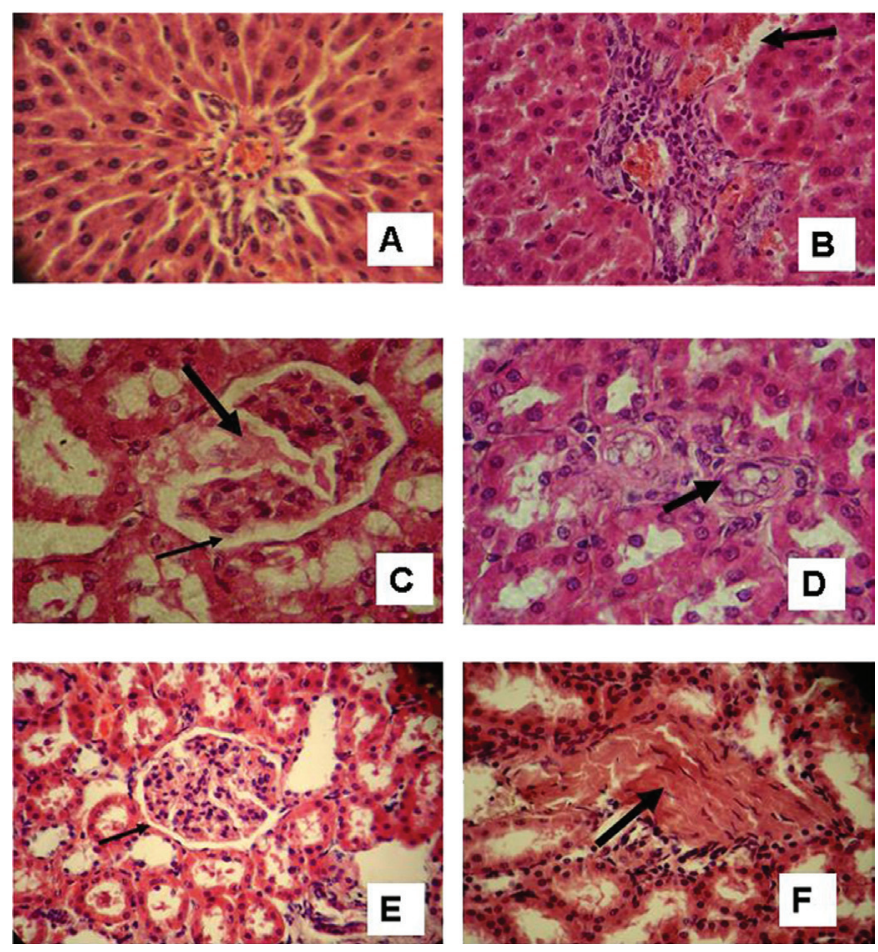

FIGURE 3 - Effects of the different treatments on histopathological parameters of liver and kidneys: A: Normal liver from water control group, HE-stained, showing portal triad, 250X. B: Liver from diabetic animal with inflammatory process in the portal triad and enlarged stroma (arrow), 250X. $\mathrm{C}$ : Kidney from diabetic rat treated with water displaying altered glomerular morphology, inflammatory process in renal papilla (large arrow) and dilatation of tubules (thin arrow), 400X. D: Kidney with concentric fibrosis from diabetic rat treated with water (arrow), 400X. E: Kidney with normal glomerular morphology (arrow) from diabetic rat treated with decoct, 400X. H: Fibrotic scar (arrow) in renal cortex of diabetic rat treated with decoct, 250X. 
In both groups of control rats, the kidney presented a typical histological structure. In the kidneys of the untreated diabetic rats (Figure 3C), many pathological alterations were found: partial cellular lesion with acidophilic material in the glomerulus, concentric fibrosis with distortion of the tubular wall and enlargement of the tubular lumen (Figure 3D), vacuolization of the cytoplasm of the tubular epithelium cells; atypical nuclei, and inflammatory processes in the interstitial spaces in renal papilla and pelvis regions. These alterations are typical of diabetic nephropathy (Thorup et al., 2000). The diabetic rats treated with $C$. xanthocarpa decoction displayed no glomerular or tubular pathological alterations (Figure 3E). Inflammatory processes were absent, but fibrotic scars were found (Figure 3F). These findings suggest that treatment with C. xanthocarpa may have an anti-inflammatory effect on the kidneys.

In summary, in the present study, STZ was able to induce typical signs of diabetes, such as weight reduction, polyphagia, polydypsia, polyuria, hyperglycemia, reduced hepatic glycogen levels and nephropathy. Treatment of the STZ rats with C. xanthocarpa decoction significantly reduced their glycemic levels, restored hepatic glycogen levels, and produced favorable histopathological results, preserving the pancreatic islets and the kidneys. Moreover, the decoction of C. xanthocarpa had no diuretic effect in the control or diabetic groups, where diuresis is a common side effect of many teas and herbal infusions.

The presence of quercetin, myricetin, quercitrin and rutin in the decoct of C. xanthocarpa was reported by Schmeda-Hirschmann (1995). This phytochemical profile suggests that flavonoids (probably quercetin) may be responsible for the effects of this decoction. The antioxidant quercetin may act on STZ-induced diabetic rats in a number of ways. It may help by improving the secretion of insulin or by increasing the glucose uptake by the tissues (Broadhurst et al., 2000). Another study showed that quercetin, at doses of $10-50 \mathrm{mg} / \mathrm{kg}$ body mass, was capable of normalizing blood glucose level, increasing liver glycogen content, and significantly reducing serum cholesterol and LDL concentration in alloxan-diabetic rats (Nuraliev, Avezov, 1992). Vessal et al. (2003) reported a significant increase in the number of pancreatic islets in both normoglycemic and diabetic rats treated with quercetin at 10 and $15 \mathrm{mg} / \mathrm{kg}$ doses. These authors argued that quercetin may act on islet functions, increasing the number of pancreatic islets and stimulating insulin release in STZdiabetic rats, as well as inducing the hepatic glucokinase enzyme in the liver. According to Vessal et al. (2003), the increase in hepatic glucokinase activity can be considered an indirect indicator of insulin release by $\beta$ cells.
In conclusion, these findings suggest a beneficial role of the C. xanthocarpa decoct on the diabetic status of STZ-treated rats. However, additional pharmacological, toxicological and histopathological studies are necessary to determine the probable mechanisms of action of $C$. xanthocarpa decoct.

\section{ACKNOWLEDGEMENTS}

This research was sponsored and supported by ULBRA. The authors are grateful to Dr. Sérgio Bordignon for the identification of the botanical material and to MS Vivian Bachim Magalhães for reviewing the manuscript.

\section{REFERENCES}

AHMED, I.; ADEGHATE, E.; SHARMA, A. K.; PALLOT, D. J. SINGH, J. Effects of Momordica charantia fruit juice on islet morphology in the pancreas of streptozotocin-diabetic rat. Diabetes Res. Clin. Pract., v.40, p.145-151, 1998.

BALLVÉ, A. C.; SIQUEIRA, N. C. S.; MENTZ, L. A.; SILVA, G. A. B; JOSÉ, K. F. D. Plantas medicinais de uso popular. Atlas Farmacognóstico. Canoas: Editora da ULBRA, 1995. p.205.

BARBOSA-FILHO, J. M.; VASCONCELOS, T. H. C.; ALENCAR, A. A.; BATISTA, L. M.; OLIVEIRA, R. A. G.; GUEDES, D. N.; FALCÃO, H. S.; MOURA, M. D.; DINIZ, M. F. F. M.; MODESTO-FILHO, J. Plants and their active constituents from South, Central, and North America with hypoglycemic activity. Rev. Bras. Farmacogn., v.15, p.392-413, 2005.

BIAVATTI, M. W.; FARIAS, S. N.; PRADO, S. R. T. Preliminary studies on Campomanesia xanthocarpa (Berg.) and Cuphea carthagenesis (Jacq.) J. F. Macbr. aqueous extract: weight control and biochemical parameters. J. Ethnopharmacol., v.393, p.385-389, 2004.

BROADHURST, C. L.; POLANSKY, M. M.; ANDERSON, R. A. Insulin like biological activity of culinary and medicinal plant aqueous extraction in vitro. J. Agri. Food Chem., v.48, p.849-52, 2000.

CAVALLI, V. L. L. O.; SORDIL, C.; TONINIL, K.; GRANDOL, A.; MUNERONL, T.; GUIGIL, A.; ROMAN-JÚNIOR, W. A. Avaliação in vivo do efeito hipoglicemiante de extratos obtidos da raiz e folha de bardana Arctium minus (Hill.) Bernh. Rev. Bras. Farmacogn., v.17, p.64-70, 2007. 
DIANI, A. R.; SAWADA, G.; WYSE, B.; MURRAY, F. T.; KHAN, M. Pioglitazone preserves pancreatic islet structure and insulin secretory function in three murine models of type 2 diabetes. Am. J. Physiol. Endocrinol. Metab., v.286, p.E116-E122, 2004.

DICKEL, M. L.; RATES, S. M. K.; RITTER, M. R. Plants popularly used for losing weight purposes in Porto Alegre, South Brazil. J. Ethnopharmacol., v.109, p.60-71, 2007.

DOBRZYNSKI, E.; MONTANARI, D.; AGATA, J.; ZHU, J.; CHÃO, J.; CHÃO, L. Adrenomedullin improves cardiac function and prevents renal damage in streptozotocininduced diabetic rats. Am. J. Physiol. Endocrinol. Metab., v.283, p.1291-1298, 2002.

FERNANDES, J. B. F.; VARGAS, V. M. S. Mutagenic and antimutagenic potential of the medicinal plant $M$. laevigata and C. xanthocarpa. Phytochem. Res., v.17, p.269-273, 2003.

FERREIRA, L. D. M. C. B.; BRÄU, L.; NIKOLOVSKI, S.; RAJA, G.; PALMER, T. N.; FOURNIER, A. P. Effect of streptozotocin-induced diabetes on glycogen resynthesis in fasted rats post-high-intensity exercise. Am. J. Physiol. Endocrinol. Metab., v.280, p.83-91, 2001.

GEARY, N.; LANGHANS, W.; SCHARRER, E. Metabolic concomitants of glucagons-induced suppression of feeding in the rat. Am. J. Physiol. Regul. Integr. Comp. Physiol., v.241, p.R330-R335, 1981.

GROVER, J. K.; YADAV, S.; VATS, V. Medicinal plants of India with anti-diabetic potential. J. Ethnopharmacol., v.81, p.81-100, 2002.

HIGA, M.; ZHOU, Y. T.; RAVAZZOLA, M.; BAETENS, D.; OREI, L.; UNGER, R. H. Troglitazone prevents mitochondrial alterations, beta cell destruction, and diabetes in obese prediabetic rats. Proc. Natl. Acad. Sci. USA, v.96, p.11513-11518, 1999.

JIANG, G.; ZHANG, B. B. Glucagon and regulation of glucose metabolism. Am. J. Physiol. Endocrinol. Metab., v.284, p.E671-E678, 2003.

KESARI, A. N.; GUPTA, R. K.; SINGH, S. K.; DIWAKAR, S.; WATAL, G. Hypoglycemic and antihyperglycemic activity of Aegle marmelos seed extract in normal and diabetic rats. J. Ethnopharmacol., v.107, p.374-379, 2006.
MARKMAN, B. E. O.; BACHI, E. M.; KATO, E. T. M. Antiulcerogenic effects of Campomanesia xanthocarpa. J. Ethnopharmacol., v.94, p.55-57, 2004.

NURALIEV, I. N.; AVEZOV, G. A. The efficacy of quercetin in alloxan diabetes. Eks. Klin. Farmakol., v.55, p.42-44, 1992.

OLIVEIRA, H. C.; SANTOS, M. P.; GRIGULO, R.; LIMA, L. L.; MARTINS, D. T. O.; LIMA, J. C. S.; STOPPIGLIA, L. F.; LOPES, C. F.; KAWASHITA, N. H. Antidiabetic activity of Vatairea macrocarpa extract in rats. J. Ethnopharmacol., v.115, p.515-519, 2008.

PUSHPARAJ, P. N.; LOW, H. K.; MANIKANDAN, J.; TAN, B. K. H.; TAN, C. H. Anti-diabetic effects of Cichorium intybus in streptozotocin-induced diabetic rats. J. Ethnopharmacol., v.111, p.430-434, 2007.

REVILLA-MONSALVE, M. C.; ANDRADE-CETTO, A.; PALOMINO-GARIBAY, M. A.; WIEDENFELD, H.; ISLAS-ANDRADE, S. Hypoglycemic effect of Cecropia obtusifolia Bertol aqueous extracts on type 2 diabetic patients. J. Ethnopharmacol., v.111, p.636-640, 2007.

SÁNCHEZ-SALGADO, J. C.; ORTIZ-ANDRADE, R. R.; AGUIRRE-CRESPO, F.; VERGARA-GALICIA, J.; LEONRIVERA, I.; MONTES, S.; VILLALOBOS-MOLINA, R.; ESTRADA-SOTO, S. Hypoglycemic, vasorelaxant and hepatoprotective effects of Cochlospermum vitifolium (Willd.) Sprengel: A potential agent for the treatment of metabolic Syndrome J. Ethnopharmacol., v.109, p.400405, 2007.

SAlGADO, L. R. Diabetes. São Paulo: Ed. Contexto, 1998. $63 \mathrm{p}$.

SAVAGE, D. B.; PETERSEN, K. F.; SHULMAN, G. I. Disordered lipid metabolism and the pathogenesis of insulin resistance. Physiol. Rev., v.87, p.507-520, 2007.

SCHOENFELDER, T.; CIRIMBELLI, T. M.; CITADINIZANETTE, V. Acute effect of Trema micrantha (Ulmaceae) on serum glucose levels in normal and diabetic rats $J$. Ethnopharmacol., v.107, p.456-459, 2006.

SCHMEDA-HIRSCHMANN, G. Flavonoids from Calycorectes, Campomanesia, Eugenia and Hexachlamys species. Fitoterapia, v.66, p.373-374, 1995. 
STUMVOLL, M.; GOLDSTEIN, B. J.; VAN HAEFTEN, T. W. Type 2 diabetes: principles of pathogenesis and therapy. Seminar, v.365, p.1333-1346, 2005.

TANG, L. Q.; WEI, W.; CHEN, L. M.; LIU, S. Effects of berberine on diabetes induced by alloxan and a high-fat/ high cholesterol diet in rats. J. Ethnopharmacol., v.108, p.109-115, 2006.

TECKMAN, J. H.; AN, J. K.; LOETHEN, S.; PERLMUTTER, D. H. Fasting in a1-antitrypsin deficient liver: constitutive activation of autophagy. Am. J. Physiol., v.263, p.G1156-G1165, 2002.

THORUP, C.; OllerstaM, A.; PERSSON, E. G.; TORFFVIT, O. Increased tubuloglomerular feedback reactivity is associated with increased NO production in the streptozotocin-diabetic rat. J. Diabetes Compl., v.14, p.46-52, 2000.
TIWARI, A. K.; RAO, J. M. Diabetes mellitus and multiple therapeutic approaches of phytochemicals: Present status and future prospects. Curr. Sci., v.83, p.30-38, 2002.

TOLOSA, E. M. C.; RODRIGUES, C. J.; BEHMER, A. O.; NETO, A. G. F. Manual de técnicas para histologia normal e patológica. 2.ed. São Paulo: Ed. Manole, 2003. p.311.

VAN HANDEL, E. Determination of glycogen in small amounts of tissue. Anal. Biochem., v.11, p.256-265, 1965.

VESSAL, M.; HEMMATI, M.; VASEI, M. Antidiabetic effects of quercetin in streptozocin-induced diabetic rats. Comp. Biochem. Physiol., part C, v.135, p.357-364, 2003.

WORLD HEALTH ORGANIZATION. Diabetes Programme. Available at: $<$ http://www.who.int/diabetes $>$. Accessed on: 17 jan. 2008.

Received for publication on $14^{\text {th }}$ January 2009 Accepted for publication on $16^{\text {th }}$ November 2009 